\title{
PENGARUH PENGGUNAAN LIMBAH WORTEL (Daucus carota L.) DALAM RANSUM SAPI PERAH BERBASIS RUMPUT LAPANGAN TERHADAP FERMENTABILITAS DAN KECERNAAN (IN VITRO)
}

\author{
(The Effect Of Use Of Carrot Waste (Daucus carota L.) In Dairy Cow Ration Based On Native \\ Grass Towards Fermentability And Digestibility (In Vitro)
}

\author{
Ai Neni Nurhayati, Ana Rochana Tarmidi, Ujang Hidayat Tanuwiria, Iman Hernaman \\ Fakultas Peternakan Universitas Padjadjaran \\ Jl. Raya Bandung Sumedang Km 21 Jatinangor Sumedang 45363 \\ e-mails: iman.hernaman@unpad.ac.id
}

Article Submitted : 04-4-2020

Article Accepted :05-6-2020

\begin{abstract}
S
Carrot waste grows in the highlands and has the potential to feed of dairy cows. The aim of this research is to utilize carrot waste in dairy cow ration and its impact on fermentability and digestibility in vitro. The study was conducted experimentally using a completely randomized design. Data were analyzed using variance analysis and Duncan's test. Analysis of the relationship between variables using correlation-regression analysis. The treatments (as fed) consist of: $\mathrm{T} 0=$ Concentrate $+100 \%$ Native Grass (Basal Ration), $\mathrm{T} 1=$ Concentrate $+50 \%$ Native Grass $+50 \%$ Carrot Leaves, T2 $=$ Concentrate $+50 \%$ Native Grass $+25 \%$ Carrot Leaves $+25 \%$ Carrot Meal, T3 $=$ Concentrate $+50 \%$ Native Grass $+50 \%$ Carrot Meal, each repeated 4 times. The results showed that the use of carrot waste did not affect ammonia production, but affected the production of flying fatty acids, dry matter digestibility and organic matter digestibility. Flying fatty acids, digestibility of dry matter, digestibility of organic matter is higher in rations using carrot waste compared to basic rations. The highest value of volatile fatty acids, dry matter digestibility and organic matter digestibility were obtained in the treatment of $50 \%$ carrot tuber replacing field grass (T3), which were $139.53 \mathrm{mM}, 56.21 \%$ and $58.86 \%$, respectively. Between the digestibility of dry matter and organic matter has a very close relationship with the regression equation $\mathrm{y}=0.9135 \mathrm{x}+7.3654$ and a correlation value of $\mathrm{r}=$ 0.8814. The results of this study can be concluded that the use of carrot waste can increase the production of volatilr fatty acids, dry matter digestibility and organic matter with the use of carrot male by $50 \%$ (as fed) as a substitute for field grass gives the best results.
\end{abstract}

Keywords: carrot waste, dairy cow, in vitro, ruminant

\section{PENDAHULUAN}

Pakan merupakan faktor yang paling banyak memerlukan biaya dalam suatu usaha peternakan karena sangat berpengaruh pada produktivitas ternak. Salah satu upaya untuk meningkatkan produktivitas ternak adalah penyediaan pakan berkualitas yang dapat memenuhi kebutuhan nutrien ternak. Oleh karena itu, kualitas pakan perlu diperhatikan dalam upaya memperoleh hasil produksi yang diinginkan. 
Sapi perah memanfaatkan hijauan sebagai sumber utama pakannya. Pada umumnya sumber yang diberikan adalah rumput-rumputan, akan tetapi seiring dengan meningkatnya intensitas pembangunan, berdampak pula terhadap ketersediaan lahan khususnnya lahan sumber penyediaan hijauan. Lahan ini pun harus bersaing dengan lahan budidaya tanaman pangan yang sekarang ini sangat mendominasi lahan pertanian di Indonesia. Adanya dominasi ini menyebabkan sebagian besar peternak rakyat memanfaatkan limbah sayuran sebagai sumber pakan hijauan.

Salah satu jenis sayuran yang produksinya cukup melimpah adalah wortel. Berdasarkan data dari Kementrian Pertanian produksi wortel tahun 2018 mencapai 609.630 ton, sedangkan limbah yang dihasilkan dari panen wortel cukup banyak, yaitu sekitar 5\% umbi wortel (Taher dkk., 2012) dan 20,13\% daun wortel (Muryanto dkk., 2019) dari total produksi. Limbah wortel ini adalah bagian aerial tanaman wortel yang umumnya lebih dikenal dengan daun wortel (Muryanto dkk., 2019) dan juga umbi wortel afkir yang tidak lolos pada saat pernyortiran (Taher dkk., 2012), sehingga tidak layak untuk dijual ke pasaran karena bentuknya terlalu kecil atau rusak akibat pemanenan yang salah (human eror).

Umbi wortel mengandung karbohidrat non struktural yang sangat tinggi yang mudah dicerna. Karbohidrat non struktural ini mudah dipecah,sehingga tidak tertutup kemungkinan pengeluaran gas yang cepat dan tinggi pula. Guna mencegah efek negatif dari pengeluaran gas berlebih ini, maka diduga pemberiannya harus digabung dengan sumber hijauan lain yang mengandung serat kasar tinggi. Umumnya jenis rumput yang diberikan oleh peternak adalah rumput lapangan. Rumput lapangan mengandung serat kasar yang cukup tinggi yang dapat menghambat pembentukan gas yang cepat. Disamping memiliki kekurangan, limbah wortel khususnya umbi wortel memiliki kelebihan yang dapat digunakan sebagai pakan alternatif, yaitu nilai karbohidrat dan antioksidan (Tamzil, 2014) yang dapat melindungi aktivitas mikroba rumen.

Wortel tumbuh di dataran tinggi, di beberapa tempat usaha peternakan sapi perah berdampingan dengan budidaya wortel. Di peternak sapi perah rakyat di daerah Cikajang Garut limbah wortel sudah digunakan oleh mereka. Oleh peternak daun wortel diberikan sebanyak 50-80\% dari total pemberian hijauan dan ternyata dapat meningkatkan produksi susu sebanyak 1-2 L per hari dan pemberian umbi wortel sebanyak $50 \%$ dari banyaknya rumput yang diberikan dapat meningkatkan produksi susu 1,5-3 L. Penggunaan daun wortel lebih banyak dilakukan dibandingkan umbi, karena harga umbi wortel jauh lebih mahal, sedangkan daun wortel dapat dicari sendiri oleh peternak.

\section{METODE PENELITIAN}

Ransum yang digunakan pada penelitian ini terdiri atas konsentrat sapi perah, rumput lapangan, dan limbah wortel. Konsentrat diperoleh dari Koperasi Peternak Garut Selatan (KPGS), rumput lapangan dan limbah wortel yang digunakan diperoleh dari perkebunan rakyat Pamegatan, Desa Pamegatan, Kecamatan Cikajang, Kabupaten Garut. Limbah wortel yang digunakan terdiri atas daun wortel yang telah diafkir. Daun wortel diperoleh dari lokasi perkebunan, sedangkan umbi wortel diperoleh dari tempat pernyortiran atau 
pengumpulan. Ransum penelitian terdiri atas empat macam perlakuan yang disusun berdasarkan kondisi segar (as feed) disesuaikan dengan yang terjadi di lapangan. Perbandingan rumput dan konsentrat $66 \%$ : $34 \%$ sebagai ransum basal :

$\mathrm{T} 0=$ Konsentrat $+100 \%$ Rumput Lapangan (Ransum Basal)
$\mathrm{T} 1=$ Konsentrat $+50 \%$ Rumput Lapangan + $50 \%$ Daun Wortel

$\mathrm{T} 2=$ Konsentrat $+50 \%$ Rumput Lapangan + $25 \%$ Daun Wortel $+25 \%$ Umbi Wortel

$\mathrm{T} 3=$ Konsentrat $+50 \%$ Rumput Lapangan + $50 \%$ Umbi Wortel

Susunan dan kandungan zat-zat makanan ransum penelitian disajikan pada Tabel 2

Tabel 1. Kandungan nutrien bahan pakan penyusun ransum perlakuan

\begin{tabular}{lcccc}
\hline \multicolumn{1}{c}{ Nutrien } & Konsentrat & $\begin{array}{c}\text { Rumput } \\
\text { Lapangan }\end{array}$ & Daun Wortel & Umbi Wortel \\
\hline Air (\%) & 11,28 & 75,04 & 74,1 & 82,91 \\
Bahan Kering (\%) & 88,72 & 24,96 & 25,9 & 17,09 \\
Protein Kasar (\%) & 8,17 & 12,35 & 14,84 & 6,97 \\
Lemak Kasar (\%) & 14,15 & 1,98 & 5,03 & 8,25 \\
Serat Kasar (\%) & 9,39 & 30 & 20,95 & 5,12 \\
Bahan Ekstrak Tanpa & & & & \\
Nitrogen (BETN) & 52,46 & 43,72 & 43,09 & 72,27 \\
Abu (\%) & 15,83 & 11,95 & 16,09 & 7,39 \\
\hline
\end{tabular}

Sumber : Laboratorium Nutrisi Ternak Ruminansia dan Kimia Makanan Ternak, Fakultas Peternakan, *Sutardi (1983), **Kearl (1982).

Tabel 2. Susunan bahan pakan dan kandungan nutrien ransum percobaan

\begin{tabular}{lcccc}
\hline Bahan Pakan & T0 & T1 & T2 & T3 \\
\hline Konsentrat & 33,68 & 33,26 & 35,3 & 37,61 \\
Rumput Lapangan (\%) & 66,32 & 32,75 & 34,76 & 37,03 \\
Daun Wortel (\%) & 0,00 & 33,99 & 18,04 & 0 \\
Umbi Wortel (\%) & 0,00 & 0,00 & 11,90 & 25,36 \\
\hline Total & 100,00 & 100,00 & 100,00 & 100,00 \\
\hline Kandungan Zat Makanan & & & & \\
\hline Bahan Kering & 46,43 & 46,22 & 46,70 & 46,94 \\
Protein Kasar (\%) & 10,94 & 11,71 & 10,69 & 9,42 \\
Lemak Kasar (\%) & 6,07 & 6,92 & 7,48 & 8,14 \\
Serat Kasar (\%) & 23,06 & 19,98 & 18,13 & 15,95 \\
Bahan Ekstrak Tanpa Nitrogen & & & & \\
(BETN) & 46,67 & 45,88 & 50,09 & 52,24 \\
Abu (\%) & 13,25 & 14,48 & 13,51 & 12,25 \\
\hline
\end{tabular}

Keterangan : untuk menghitung kandungan zat makanan didasarkan pada 100\% bahan kering

Ransum penelitian tersebut dilakukan pengujian secara in vitro dengan menggunakan metode Tilley dan Terry (1963). Cairan rumen yang digunakan 
berasal dari cairan rumen sapi perah yang dipotong di rumah pemotongan hewan (RPH) Ciroyom, Bandung. Peubah yang diukur adalah produksi ammonia $\left(\mathrm{N}-\mathrm{NH}_{3}\right)$ menggunakan metode mikrodifusi cawan Conway, sedangkan asam lemak terbang (ALT) menggunakan metode destilasi uap Markham. Pengukuran kecernaan bahan kering dan kecernaan bahan organik menggunakan metode yang dijelaskan oleh Hernaman dkk.(2005).

Data yang terkumpul kemudian dianalisis dengan sidik ragam pada taraf $\alpha=0,05 \%$ dan bila terjadi perbedaan secara nyata dilakukan analysis dengan menggunakan uji Duncan. Untuk mengukur hubungan anatara kecernaan baha kering dan bahan organik menggunakan analisis korelasi dan regresi (Steel dan Torrie.1993).

\section{HASIL DAN PEMBAHASAN}

\section{Kondisi Ransum Percobaan}

Ransum basal yang digunakan didasarkan pada kondisi nyata yang terdapat di peternak sapi perah di daerah Garut Selatan. Ransum basal memiliki perbandingan antara rumput lapangan dengan konsentrat adalah 66\%: $34 \%$ berbasis bahan kering. Penggunaan rumput lapangan sebagai basis utama hijauan pada kenyataannya di lapangan digantikan dengan limbah wortel. Agar disesuaikan dengan kondisi yang sesuai dengan yang ada di lapangan, maka perhitungannya didasarkan pada as feed, dimana posisi rumput lapang sebagai hijauan $100 \%$, digantikan sebagian oleh daun wortel sebesar 50\% (T1), 25\% daun wortel dan $25 \%$ umbi wortel (T2), dan $50 \%$ umbi wortel (T3). Kondisi tersebut di atas, jika dikonversi dalam bahan kering $100 \%$ akan mengubah perbandingan antara konsentrat dengan sumber hijauan (Tabel 2), karena masing-masing hijauan memiliki kadar air yang berbeda (Tabel 1). Konsentrat dihitung secara asf ed diberikan dalam jumlah yang sama untuk semua perlakuan.

Tabel 2. menggambarkan bahwa penggunaan daun wortel meningkatkan kandungan protein ransum, sebaliknya penggunaan umbi wortel menurunkan kandungan protein ransum. Hal ini karena daun wortel lebih tinggi kandungan proteinnya dibandingkan dengan umbi wortel maupun dengan rumput lapang (Tabel 1). Kandungan lemak kasar ransum meningkat seiring dengan penggunaan limbah wortel karena lemak yang terkandung pada daun dan umbi wortel lebih tinggi dibandingkan dengan rumput lapang. Di pihak lain, serat kasar menurun seiring dengan penggunaan limbah wortel, karena limbah tersebut mengandung serat kasar yang lebih rendah dibandingkan dengan rumput lapangan. Daun wortel merupakan hijauan yang memiliki kadar abu tinggi, sedangkan umbi wortel kaya akan BETN, komponen nutrien yang berbeda akan menjadikan kandungan abu dan BETN pada masing-masing perlakuan juga berbeda.

\section{Pengaruh Ransum Perlakuan terhadap Fermentabilitas dan Kecernaan Ransum secara In Vitro}

Fermentabilitas dan kecernaan ransum percobaan secara in vitro disajikan pada Tabel 3. Produksi ammonia menunjukkan tidak berbeda nyata dengan nilai rataan berkisar 2,22-2,35 mM. Nilai ini di bawah kisaran normal untuk pertumbuhan mikroba rumen yaitu 4,08 - 8,09 $\mathrm{mM}$ (Sutardi, 2003). Asam lemak terbang, kecernaan bahan kering dan kecernaan bahan organik menunjukan adanya perbedaan yang nyata $(\mathrm{P}<0,05)$ dengan nilai tertinggi diperoleh pada perlakuan $\mathrm{T} 3$, yaitu 
perlakuan penggunaan umbi wortel dalam ransum sebanyak 50\% (segar/as fed) yang menggantikan rumput lapangan sebagai sumber hijauan, yaitu secara berturut turut sebesar $139,53 \mathrm{mM}, 56,21 \%$ dan $58,86 \%$.
Kecernaan bahan kering memiliki pola yang sama dengan kecernaan bahan organik dan kecernaan bahan organik lebih tinggi prosentasenya dibandingkan dengan kecernaan bahan kering.

Tabel 3. Pengaruh perlakuan terhadap fermentabilitas dan kecernaan secara in vitro

\begin{tabular}{|c|c|c|c|c|}
\hline Peubah & T0 & $\mathrm{T} 1$ & $\mathrm{~T} 2$ & T3 \\
\hline Ammonia/N-NH $3(\mathrm{mM})$ & $2,28 \pm 0,11$ & $2,35 \pm 0,07$ & $2,33 \pm 0,11$ & $2,22 \pm 0,14$ \\
\hline Asam Lemak Terbang (mM) & $95,88 \pm 15,24^{\mathrm{a}}$ & $118,63 \pm 10,46^{\mathrm{ab}}$ & $119,25 \pm 12,55^{\mathrm{ab}}$ & $139,53 \pm 36,07^{b}$ \\
\hline Kecernaan Bahan Kering (\%) & $46,22 \pm 0,85^{\mathrm{a}}$ & $48,62 \pm 0,84^{\mathrm{ab}}$ & $49,96 \pm 1,67^{\mathrm{b}}$ & $56,21 \pm 3,31^{\mathrm{c}}$ \\
\hline Kecernaaan Bahan Organik (\%) & $48,36 \pm 0,99^{\mathrm{a}}$ & $51,45 \pm 2,05^{\mathrm{b}}$ & $54,40 \pm 1,00^{\mathrm{c}}$ & $58,86 \pm 2,88^{\mathrm{d}}$ \\
\hline
\end{tabular}

Keterangan : Superskrip berbeda pada baris yang sama menunjukkan berbeda nyata $(\mathrm{P}<0,05)$.

Produksi ammonia untuk semua perlakuan tidak berbeda nyata dan menunjukan konsentrasi yang rendah di bawah rekomendasi untuk kebutuhan bagi aktivitas mikroba rumen dalam proses fermentasi. Hal ini disebabkan karena kandungan protein kasar ransum untuk semua perlakuan dalam kondisi rendah, yaitu pada kisaran 9,42-11,71\%. Dengan rendahnya protein ransum akan difermentasi secara maksimal oleh mikroba rumen menjadi $\mathrm{N}-\mathrm{NH}_{3}$, sehingga hasilnya tidak berbeda nyata. Protein pada konsentrat yang digunakan sangat rendah hanya $8,17 \%$ padahal konsentrat untuk sapi perah diharapkan mengandung protein tinggi. Protein yang rendah pada konsentrat akan menyumbang protein yang rendah bagi ransum. Standar nasional kandungan konsentrat untuk sapi perah berkisar 15-18\% (Aprilia dkk. 2018).

Asam lemak terbang tertinggi diperoleh pada perlakuan T3 karena ransum tersebut mengandung karbohidrat non struktural dalam bentuk BETN yang paling tinggi $(52,24 \%)$ dengan kandungan serat kasar yang paling rendah $(15,95 \%)$. BETN lebih mudah difermentasi menjadi asam lemak terbang dibandingkan dengan serat kasar. Tingginya BETN pada perlakuan T3 karena sumbangan BETN yang tinggi dari umbi wortel, karena kandungan BETN-nya sebesar $72,27 \%$ yang merupakan protein kasar yang paling tinggi diantara bahan pakan yang digunakan. Di samping itu, BETN yang terkandung dalam umbi wortel kaya akan gula-gula pereduksi dan non pereduksi berupa fruktosa, sukrosa, dekstrosa, laktosa, dan maltose (Rukmana, 1995). Gula-gula tersebut merupakan bagian dari karbohidrat yang mudah difermentasi oleh mikroba rumen. Kemungkinan lainnya adalah limbah wortel kaya dengan antioksidan yang dapat berfungsi untuk melindungi sel dari kerusakan yang disebabkan oleh radikal bebas (Tamzil 2014), sehingga dapat membantu meningkatkan daya hidup sel mikroba rumen yang berdampak dapat meningkatkan proses fermentasi terutama karbohidrat menjadi asam lemak terbang.

Produksi asam lemak terbang yang tinggi mencerminkan bahwa bahan pakan tersebut mudah difermentasi. Proses fermentasi di rumen melibatkan enzim 
mikroba rumen yang memecah senyawa kompleks menjadi lebih sederhana (Hernaman, 2010). Asam lemak terbang merupakan hasil fermentasi karbohidrat yang merupakan porsi terbesar dalam ransum ruminansia, sehingga jika asam lemak terbang tinggi maka mencerminkan tingkat kecernaan yang tinggi. Ransum T3 yang memiliki tingkat kecernaan bahan kering yang paling tinggi akibat dari proses fermentasi yang tinggi karena ransum mudah difermentasi yang tercermin dari kandungan asam lemak terbang yang tinggi. Menurut Saripudin, dkk. (2019) terdapat hubungan yang kuat antara produksi asam lemak terbang dengan kecernaan bahan kering maupun bahan organik, asam lemak yang tinggi akan diikuti dengan kecernaan bahan kering dan bahan organik yang tinggi pula.

Kecernaan bahan kering memiliki pola yang sama dengan kecernaan bahan organik. Pada hakekatnya kecernaan bahan organik adalah kecernaan bahan kering yang tidak memperhitungkan kecernaan abu. Kecernaan bahan organik meliputi kecernaan protein kasar, lemak kasar, serat kasar dan BETN. Nilai kecernaan bahan organik tidak terlalu jauh dibandingan dengan kecernaan bahan organik. Suparwi (2000) menyatakan bahwa bahan organic merupakan bagian dari bahan kering sehingga pada umumnya kecernaan bahan organic tidak menyimpang jauh darai bahan keringnya. Hubungan antara kecernaan bahan kering dan organik dapat dilihat dari nilai regresi dan korelasinya yang disajikan pada Gambar 1. Gambar tersebut menjelaskan adanya korelasi yang positif membentuk persamaan regresi $\mathrm{y}=0,9135 \mathrm{x}$ $+7,3654$ dengan nilai korelasi $\mathrm{r}=0,8814$. Nilai korelasi yang tinggi menggambarkan bahwa hubungan antara kecernaan bahan kering dan bahan organik sangat erat (Sugiyono, 2007). Kecernaan bahan organik lebih tinggi dibandingkan dengan kecernaan bahan kering. Hal ini karena bahan organik tidak mengandung abu, dimana nutrien ini menyebabkan terhambatnya proses pencernaan (Fathul et al., 2010).

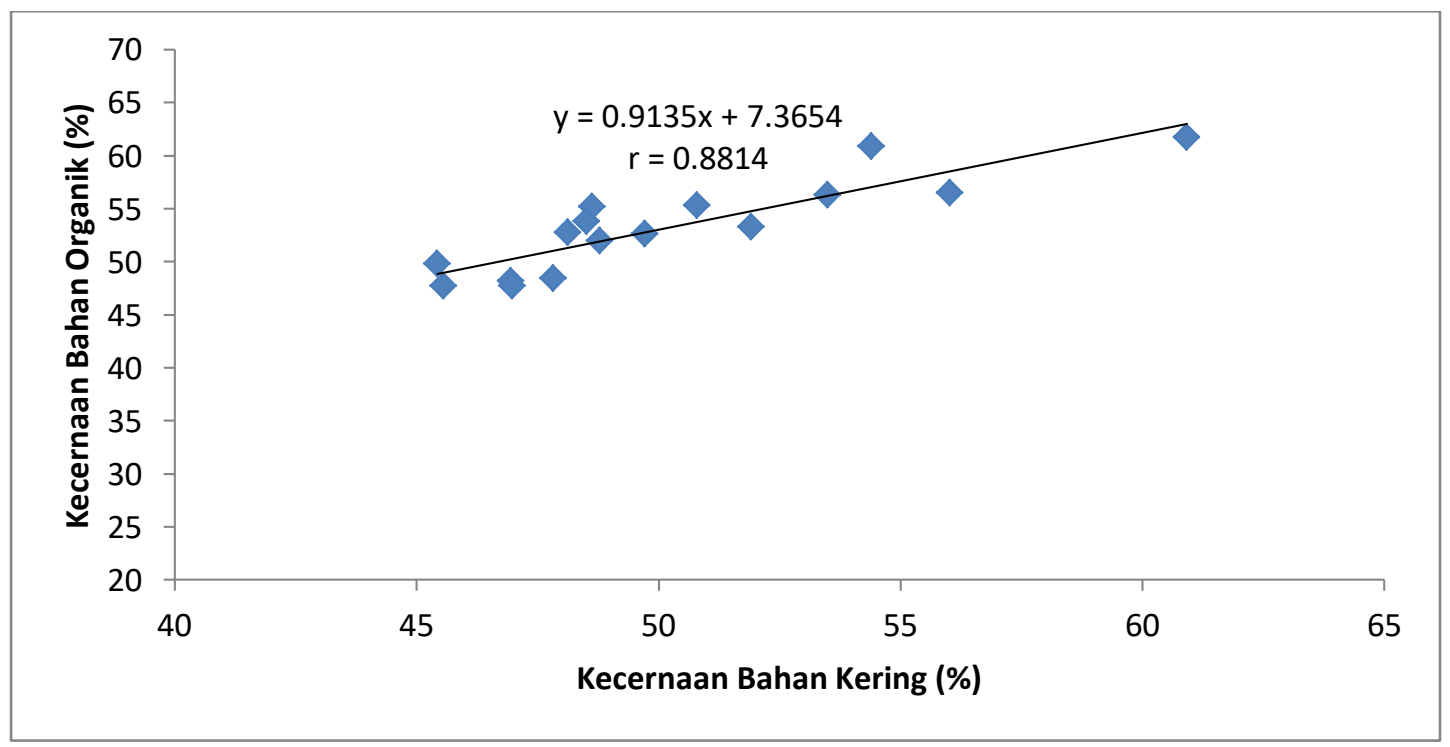

Gambar 1. Hubungan anatara kecernaan bahan kering dengan kecernaan bahan organik 


\section{KESIMPULAN}

Penggunaan limbah wortel mampu meningkatkan produksi asam lemak terbang, kecernaan bahan kering dan bahan organik dengan penggunaan umbi wortel sebanyak $50 \%$ as fed sebagai pengganti rumput lapang memberikan hasil yang terbaik.

\section{UCAPAN TERIMAKASIH}

Penelitian dilaksanakan di Laboratorium Nutrisi Ternak Ruminansia dan Kimia Makanan Ternak Fakultas Peternakan Universitas Padjadjaran serta bahan penelitian diperoleh di wilayah kerja Koperasi Peternakan Garut Selatan. Oleh karena itu, penulis mengucapkan banyak terimakasih kepada Kepala Laboratorium beserta anggota dan teknisi serta juga masyarakat peternak dan Pengurus Koperasi Garut Selatan yang telah membantu selama penelitian.

\section{DAFTAR PUSTAKA}

Aprilia, R.M., Hartutik, dan Marjuki. 2018. Evaluasi kandungan nutrien konsentrat sapi perah rakyat di Kabupaten Malang. Jurnal Nutrisi Ternak Tropis 1 (1) 54-59

Fathul, F., dan S. Wajizah. 2010. Penambahan mikromineral $\mathrm{Mn}$ dan $\mathrm{Cu}$ dalam ransum terhadap aktivitas biofermentasi rumen domba secara in vitro. JITV. 15(1): 9-15

Hernaman, I. U. H. Tanuwiria, dan M. F. Wiyatna. 2005. Pengaruh Penggunaan Berbagai Tingkat Kulit Kopi dalam Ransum Penggemukan Sapi Potong terhadap Fermentabilitas Rumen dan Kecernaan In-Vitro. Bionatura 7: 4650.
Hernaman, I, K.A. Kamil, U.H. Tanuwiria, E.S. Lestari, and T. Toharmat. 2010. Bioconversion property of tea leaves waste by Aspergillus niger as functional fiber to decrease blood lipid. J.Indonesian Trop.Anim.Agric. $35: 227-231$.

Muryanto, Amrih Prasetyo dan Heri Kurnianto. 2019. Pemanfaatan limbah daun wortel untuk pakan pada penggemukkan domba Batur. Seminar Nasional "Sumber Daya Pertanian Berkelanjutan dalam Mendukung Ketahanan dan Keamanan Pangan Indonesia pada Era Revolusi Industri 4.0" Dalam Rangka Dies Natalis UNS Ke 43 Tahun 2019.

Rukmana, R. 1995. Bertanam Wortel. Kanisius. Yogyakarta.

Saripudin A, S. Nurpauza, B. Ayuningsih, I. Hernaman dan A.R. Tarmidi. 2019. Fermentabilitas dan kecernaan ransum domba yang mengandung limbah roti secara in vitro. Jurnal Agripet 19 (2) : 8590

Suparwi. 2000. Pengaruh minyak kelapa dan kembang sepatu (Hibiscus rosasinensis) terhadap kecernaan ransum dan jumlah protozoa. Animal Production, 2(2), 53-59.

Sutardi, T. 2003. Peningkatan Produksi Ternak Ruminansia Melalui Amoniasi Pakan Serat Bermutu Rendah, Defaunasi dan Suplementasi Sumber Protein Bahan Degradasi Dalam Rumen. Laporan Penelitian. Fakultas Peternakan Institut Pertanian Bogor, Bogor.

Steel, R.G.D. and J.H. Torrie. 1993. Prinsip dan Prosedur Statistika. Edisi Kedua. PT Gramedia Pustaka, Jakarta (Diterjemahkan oleh B. Sumantri). 
Sugiyono. 2007. Metode Penelitian pendidikan pendekatan kuantitatif, kualitatif, dan $R \& D$. Bandung: ALFABETA

Taher, M., Supramana dan G. Suastika. 2012. Identifikasi Meloidogyne penyebab penyakit umbi bercabang pada wortel di Dataran Tinggi Dieng. Jurnal Fitopatologi 8(1): 16-21.
Tamzil, M. H. 2014. Stres panas pada unggas: metabolisme, akibat dan upaya penanggulangannya. Wartazoa 24 (2): 57-66

Tilley, J.M.A. dan R.A. Terry. 1963. A two stage technique for the in vitro digestion of the forage crops. J. Brit. Grassl. Soc. (18) 2 : $104-106$. 